\title{
Çeșitli Klinik Örneklerden İzole Edilen Candida İzolatlarında Biyofilm Olușumu ve Antifungal Duyarlılıklarının Belirlenmesi
}

\section{Determination of Biofilm Formation and Antifungal Sensitivity of Candida Strains Isolated from Various Clinical Samples}

\author{
Seda ACAR'(ID), Burak KÜÇÜK'(IID), Murat ARAL'(ID), Kübra DERÇiN'(ID) \\ ${ }^{1}$ Kahramanmaraș Sütçü İmam Üniversitesi Tıp Fakültesi, Tıbbi Mikrobiyoloji Anabilim Dalı, Kahramanmaraș, Türkiye
}

Makale atıfı: Acar S, Küçük B, Aral M, Derçin K. Çeşitli klinik örneklerden izole edilen Candida izolatlarında biyofilm oluşumu ve antifungal duyarlliklarinin belirlenmesi. FLORA 2021;26(1):122-8

\section{ÖZ}

Giriş: Çalışmamızın amacı tıbbi mikrobiyoloji laboratuvarına gelen klinik örneklerden izole edilen 60 Candida albicans türünde biyofilm oluşumunu tespit etmek ve antifungal duyarlııklarını belirlemektir.

Materyal ve Metod: Biyofilm oluşturma yeteneği Kongo Kırmızısı Agar ve mikroplakta XTT indirgenmesi yöntemiyle araştırılmıştır. Suşların; amfoterisin B, vorikonazol, flukonazol, kaspofungin, flusitozin duyarlılıları The European Committee on Antimicrobial Susceptibility Testing (EUCAST) önerileri doğrultusunda Broth dilüsyon metoduna göre araştırılmıstır.

Bulgular: Suşların 29'u (\%47.5) biyofilm pozitif, 32'si (\%52.4) biyofilm negatif olarak tespit edilmiştir. Biyofilm pozitif olan bu suşların 10'u zayıf biyofilm (\%34.4), 15'i orta biyofilm (\%51.7), 4'ü güçlü biyofilm (\%13.7) oluşturmuştur. Biyofilm oluşumunu saptamada mikroplakta XTT indirgenmesi testi ile Kongo Kırmızısı Agar testi aynı sonucu vermiştir. Antifungal ilaçların minimum inhibitör konsantrasyon (MiK) aralıkları vorikonazol için 0.032-4 mg/L, flukonazol için 0.064-64 mg/L, amfoterisin B için 1-4 mg/L bulunmuştur. Vorikonazol için örneklerin 53'ü (\%88.3), amfoterisin B için 56'sı (\%93.3), flukonazol için 6'sı (\%10) dirençli olarak tespit edilmiştir. Kaspofungin için MiK aralığı 0.008-4 mg/L, flusitozin için 0.064-64 mg/L olarak belirlenmiştir. Candida albicans örneklerinde amfoterisin $B$ ve vorikonazole yüksek oranda direnç saptanmıştır.

Sonuç: Kongo Kırmızısı Agar yönteminin XTT indirgenmesi yöntemine kıyasla biyofilm oluşumunu saptamada maliyet açısından daha uygun olduğu sonucuna ulaşılmıştır. Biyofilm oluşturan örneklerin antifungal MiK değerleri biyofilm oluşturmayan örneklere göre daha yüksek bulunmuştur.

Anahtar Kelimeler: Antifungal duyarlıı; Biyofilm; Candida 


\title{
ABSTRACT \\ Determination of Biofilm Formation and Antifungal Sensitivity of Candida Strains Isolated from Various Clinical Samples
}

\author{
Seda ACAR', Burak KÜÇÜK'1, Murat ARAL', Kübra DERÇiN ${ }^{1}$ \\ ${ }^{1}$ Department of Medical Microbiology, Kahramanmaraș Sütçü İmam University School of Medicine, Kahramanmaraș, Turkey
}

Introduction: The aim of this study was to determine the biofilm formation and antifungal susceptibility of 60 Candida albicans strains isolated from clinical samples in Medical Microbiology Laboratory.

Materials and Methods: Biofilm formation was investigated using Congo Red agar and XTT reduction method. Amphotericin B, voriconazole, fluconazole, caspofungin, and flucytosine susceptibility of the strains were investigated by the Broth dilution method according to the recommendations of The European Committee on Antimicrobial Susceptibility Testing (EUCAST).

Results: In both methods, 29 (47.5\%) of the strains were positive and 32 (52.4\%) strains were negative. Of the biofilm-positive strains, biofilm production level was weak in 10 strains (34.4\%), moderate in 15 strains (51.7\%) and strong in 4 strains (13.7\%). In determining biofilm formation, XTT reduction test in Microplate and Congo red agar test gave the same result. MIC ranges of antifungal drugs were 0.032-4 mg/L for voriconazole, 0.064-64 mg/L for fluconazole and 1-4 mg/L for amphotericin B. The number of voriconazole, amphotericin B and fluconazole resistant strains were 53 (88.3\%), 56 (93.3\%) and 6 (10\%) respectively. MIC ranges were 0.008-4 $\mathrm{mg} / \mathrm{L}$ for caspofungin and 0.064-64 $\mathrm{mg} / \mathrm{L}$ for flucytosine.

Conclusion: As a result, it was concluded that the Congo Red Agar method is more cost effective in detecting biofilm formation than the $X T T$ reduction method. Antifungal MIC values of biofilm forming strains were higher than non-biofilm producing strains. High resistance to amphotericin B and voriconazole was detected.

Key Words: Antifungal susceptibility; Biofilm; Candida

\section{GiRiș}

Candida spp. insan deri ve mukoza florasında yer alan mikroorganizmalardır. Sağlıklı bireylerin ağız ve gastrointestinal sistemlerinde bulunmaktadır. Predispozan faktörlerin varlığında kandidoz olarak tanımlanan yüzeyel veya derin, akut veya kronik infeksiyonlara sebep olabilmektedir ${ }^{[1]}$. Yap1lan invaziv girișimler, geniș spektrumlu antibiyotik kullanımı, immünsupresif tedaviler, HIV ile infekte popülasyonun artması gibi cesitli nedenler fungal infeksiyon görülme sıklığını artırmaktadır ${ }^{[2]}$. Candida infeksiyonunda görülen morbidite ve mortalite oranlarının artmasına; proteaz, esteraz, fosfolipaz, biyofilm gibi virulans faktörlerinin neden olduğu düsünülmektedir ${ }^{[3]}$. Bu nedenle Candida'ya ait virulans faktörleri dikkate alınarak yeni tedavi yöntemleri araștırılmaya bașlanmıștır ${ }^{[4]}$. Calıșmamızın amacı Candida albicans örneklerinde biyofilm olusumunun iki farklı yöntemle saptanması ve bu örneklerin antifungal duyarlılıklarının belirlenmesidir.

\section{MATERYAL ve METOD}

Bu calıșmaya 2018 yılında tıbbi mikrobiyoloji laboratuvarına gönderilen kan, idrar, solunum ve yara örneklerinden izole edilen 60 adet $C$. albicans izolati ve $C$. albicans ATCC 90028 standart sușu dahil edilmiștir. Calıșmaya dahil edilen Candida örneklerinin biyofilm olușturma özelliği iki farklı yöntemle belirlenmiștir.

\section{Kongo Kırmızısı Agar (KKA) Yöntemi}

Test edilecek Candida sușunun sabouraud dekstroz agarda (SDA) üretilmis taze kültüründen bir öze dolusu alınarak KKA yüzeyine ekilmiș ve petriler $35^{\circ} \mathrm{C}$ 'de 48 saat inkübe edilmistir. Sonrasında üreyen maya kolonilerinin renkleri incelenerek, sonuçar görsel olarak değerlendirilmiștir. Bu değerlendirmeye göre koloniler siyah ve bordo ise mikroorganizma biyofilm pozitif; kırmız, pembe ve beyaz ise biyofilm negatif olarak kabul edilmiștir ${ }^{[5]}$.

\section{Mikroplakta XTT İndirgenmesi ille Biyofilm Varlığının Test Edilmesi}

Bu yöntemde 96 kuyucuklu mikroplaklar kullanılmıstır. Test edilecek sușun sabouraud dextrose agarda (SDA) üretilmis 24 saatlik taze kültüründen bir öze dolusu $10 \mathrm{~mL}$ yeast peptone dextrose (YPD) sivı besiyerine konmus ve calkalayıcıda $37^{\circ} \mathrm{C}$ 'de bir gece inkübe edilmiștir. Ertesi gün, 
içinde üreme olan sıvı besiyeri içindeki maya hücreleri PBS ile üc kez yıkanarak ayrıștırılmıștır. Bunun için besiyeri 3000 rpm'de 5-10 dakika santrifüj edilmiș, üst kısımdaki sıvı dökülmüștür. Tüpte kalan cökeltiye $5 \mathrm{~mL}$ steril PBS eklenerek vortekslenmis ardından 3000 rpm'de tekrar santrifüjlenmiș ve üsteki sıvı dökülerek bu kez $2 \mathrm{~mL}$ steril PBS eklenmiștir. Yeniden vorteksleme ve santrifüj yapılmıs ve kalan cökeltiye $37^{\circ} \mathrm{C}$ sicaklıkta 1 $\mathrm{mL}$ serum fizyolojik (SF) eklenerek karıștırılmıstır. Elde edilen süspansiyondan SF içinde $1 \times 10^{6} \mathrm{CFU} /$ $\mathrm{mL}$, spektrofotometrede absorbans 0.09-0.13 ve optik dansite (OD) \%78-80 olacak sekilde süspansiyon hazırlanmıștır. Sonraki ișlem 15 dakika içinde gerçekleșmeyecek ise, hazırlanan süspansiyon buzdolabında bekletilmiștir. Mikroplaklar kontamine edilmeyecek sekilde paketlerinden çkarıldıktan sonra, test için kullanılacak her kuyucuğa $50 \mu \mathrm{L}$ RPMI 1640 konulmus ve pozitif kontrol sușu da dBhil olmak üzere sus süspansiyonlarından 50'șer $\mu \mathrm{L}$ eklenmiștir. Negatif kontrol kuyucuklarına ise sadece $50 \mu \mathrm{L}$ RPMI 1640 konulmustur. Hazırlanan test plakları kapakları kapatılıp parafilmle sarıldıktan sonra $37^{\circ} \mathrm{C}$ 'de 24 saat inkuibe edilmiștir. Üreme așamasının ardından kuyucuklarda yıkama yapilarak biyofilm olușturmayan ve cukur yüzeyine tutunamayan maya hücrelerinin uzaklaștırılması sağlanmıștır. Yıkama ișleminin ardından yapılan görsel değerlendirmede, cukurların taban kısmında tabaka olușumu gözlenmesi biyofilm varlığını, tabaka olușumu gözlenmemesi biyofilm bulunmadığını ișaret etmektedir. Sonuçlar ayrıca hücre canlılığını tayin etmede kullanilan bir kimyasal olan XTT ile spektrofotometrik olarak da değerlendirilmiștir ${ }^{[6]}$.

\section{Mayaların Antifungal Duyarlılıklarının Belirlenmesi}

Klinik suşların yanında çalıșmada standart suș olarak C. albicans ATCC 90028 kullanılmıștır. Suşların antifungal duyarlılıkları sıvı mikrodilüsyon yönteminde referans yöntemlerden biri olan The European Committee on Antimicrobial Susceptibility Testing (EUCAST) kılavuzu önerilerine göre gercekleștirilmiștir $^{[7]}$.

\section{İstatistiksel Analiz}

Verilerin değerlendirmesinde kategorik değișkenler arasındaki dağılım ilișkisi ki kare testi ve fisher exact testi ile incelenmistir. Testler arasındaki uyum Cohen Kappa katsayısı ile incelenmiștir. İstatistik parametreler oran ve frekanslar ile ifade edilmiștir. İstatistiksel anlamllık $p<0.05$ olarak ifade edilmiștir. Veriler SPSS 22.0 programında incelenmiștir.

Calıșma için Kahramanmaras Sütçü İmam Üniversitesi Tip Fakültesi Bilimsel Araștırmalar Etik Kurulundan onay alınd (Karar no: 247 Tarih: 02.11.2016).

\section{BULGULAR}

Kongo Kırmızısı Agar yöntemi ve mikroplakta XTT indirgenmesi testi ile yapılan calıșma sonucuna göre toplam 61 sușun 32'si (\%53) biyofilm negatif olarak değerlendirilirken, 29'u (\%47) biyofilm pozitif olarak tespit edilmistir. Solunum ve idrar örneklerinde biyofilm pozitifliği diğer örneklere göre daha yüksek oranda saptanmıștır. Mikroplakta XTT İndirgenmesi testi ile Kongo Kırmızısı Agar testi karșılaștırıldığında sonuçlar aynı bulunmuștur. İki test arasındaki uyum istatistiksel olarak anlamlı bulunmuștur $(\mathrm{p}<0.001)$ (Tablo 1).

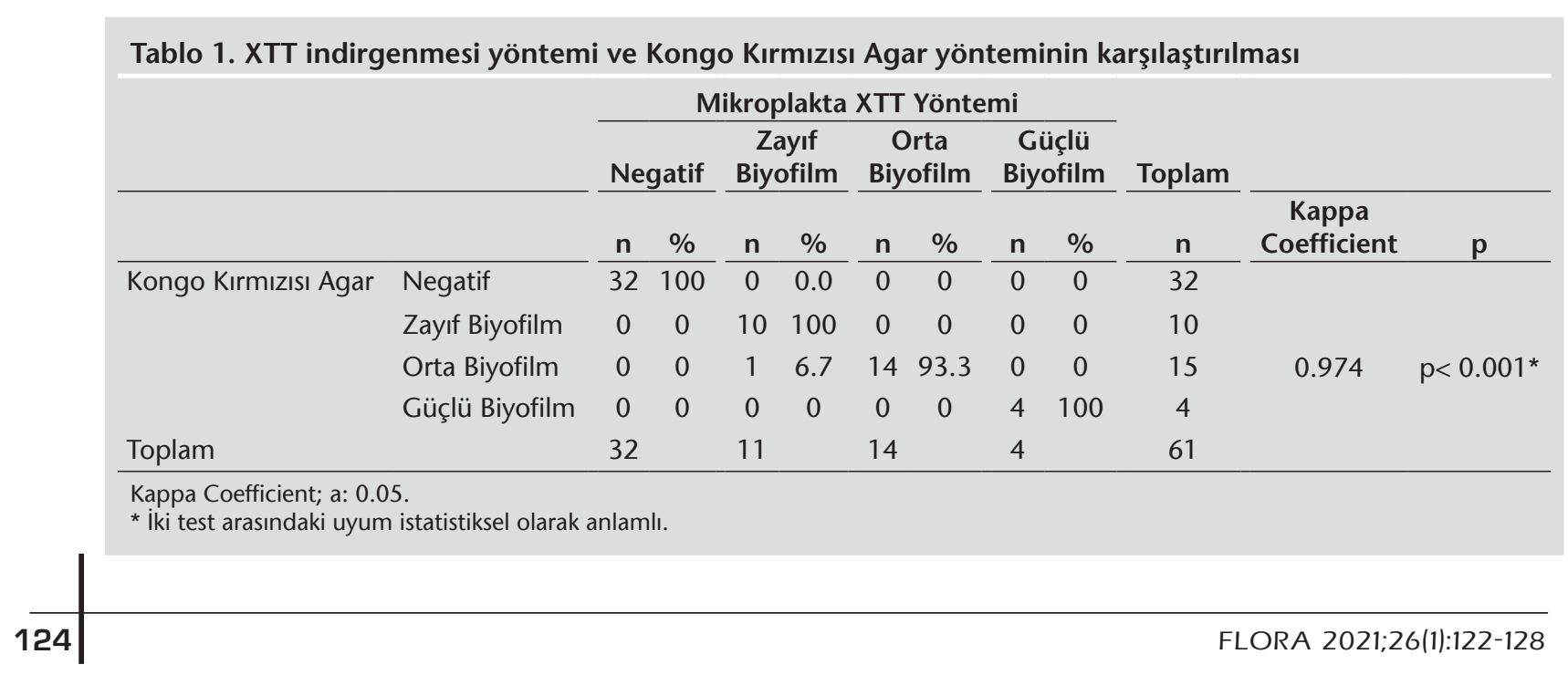




\begin{tabular}{|c|c|}
\hline Antifungal ajanlar & Mik Aralığı \\
\hline Amfoterisin B & $1.0-4 \mathrm{mg} / \mathrm{L}$ \\
\hline Flukonazol & $0.064-64 \mathrm{mg} / \mathrm{L}$ \\
\hline Flusitozin & $0.064-64 \mathrm{mg} / \mathrm{L}$ \\
\hline Kaspofungin & $0.008-4 \mathrm{mg} / \mathrm{L}$ \\
\hline Vorikonazol & $0.032-4 \mathrm{mg} / \mathrm{L}$ \\
\hline
\end{tabular}

\section{Antifungal Duyarlılık Test Sonuçları}

Biyofilm pozitif sușların antifungal MiK değerleri biyofilm negatif sușlara göre daha yüksek bulunmustur. Amfoterisin B, flukonazol, vorikonazol ve flusitozin konsantrasyon düzeylerinin biyofilm pozitif ve negatif gruplarına göre frekans dağılımındaki farkll1lkları istatistiksel olarak anlamlı bulunmuștur (Amfoterisin B için $\mathrm{p}=0.044$, flukonazol için $\mathrm{p}=$ 0.048 , vorikonazol için $p=0.029$, flusitozin için $\mathrm{p}=0.045$ ). Kaspofungin konsantrasyon düzeylerinin biyofilm pozitif ve negatif gruplarına göre frekans dağılımındaki farkllıkları istatistiksel olarak anlamlı bulunamamıstır ( $p=0.107)$. Antifungal ilaçların MiK aralıkları vorikonazol için 0.032-4 $\mathrm{mg} / \mathrm{L}$, flukonazol için 0.064-64 mg/L, amfoterisin $B$ için 1-4 mg/L aralığında bulunmuștur. Sușların vorikonazol için 53'ü (\%88.3), amfoterisin B için 56'sı (\%93.3), flukonazol için 6'sı (\%10) dirençli olarak tespit edilmiștir. Kaspofungin için MiK aralığ1 $0.008-4 \mathrm{mg} / \mathrm{L}$, flusitozin için 0.064-64 mg/L aralığında elde edilmiștir. EUCAST kaspofungin ve flusitozin için tam bir MiK değeri belirtmediğinden dirençli ve duyarlı sus sayısı belirlenememiștir. Clinical and Laboratory Standard Institute (CLSI) değerlerine göre kaspofungin için sușların 2'si direncli (\%3.33) olarak belirlenmistirir ${ }^{[8]}$. Sonuc olarak amfoterisin $\mathrm{B}$ ve vorikonazole yüksek oranda direnç saptanmıstır (Tablo 2).

\section{TARTIȘMA}

Candida spp. doğada yaygın olarak bulunmakla beraber sağlıklı bireylerin normal vücut floralarında yer almaktadır. Özellikle bağısıklık sistemi baskılanmıs bireylerde fırsatçı infeksiyonlara neden olmaktadır. Bu durum da morbidite ve mortalite oranlarında artıșa yol açmaktadır $[9,10]$.

Biyofilm kaynaklı infeksiyonların tedavisi biyofilmlerin antimikrobiyal tedaviye azalan duyarl- lıklarından dolayı zordur. Ramage ve arkadașları yaptıkları calıșmada biyofilm olușturan $C$. albicans suşlarının flukonazole karșı direnc oranlarının daha yüksek olduğunu bildirmișlerdir ${ }^{[11]}$. Karaman ve arkadașları yaptıkları calısmada biyofilm pozitif ve biyofilm negatif $C$. albicans susları ile infekte Galleria larvalarının sağkalım oranlarını karșılaștırmistır. Biyofilm pozitif $C$. albicans ile infekte larvalarda 24. saat sonunda sağkalım diğer grubun \%20'si olarak belirlenmiștir ${ }^{[12]}$. Triazol grubu antifungallerin cok sık kullanılmasından dolayı biyofilm üreten Candida türlerinde antifungal ajanlara karș1 dirençte artıs görülmeye bașlamıștır ${ }^{[13]}$. Plastik yüzeylerde üreyen $C$. albicans biyofilminin planktonik hücrelerle kıyaslandığında amfoterisin B'ye 20-30 kat fazla dirençli olduğu tespit edilmiștir ${ }^{[14]}$. Bu nedenle Candida cinsi mayaların biyofilm olusturabilme kapasiteleri, antifungal ajanlara karșı duyarlllik ve direnç durumlarının incelenmesi açısından gün gectikçe önemini artırmaktadır.

Biyofilm pozitif olarak bulduğumuz 29 sușun 10'unun (\%34.4) zayif biyofilm, 15'inin (\%51.7) orta biyofilm, 4'ünün ise (\%13.7) güçlü biyofilm olușturdukları gözlemlenmiștir. Aslan ve arkadașlar1nın yaptıkları calıșmada KKA yöntemi ile test edilen $10 \mathrm{C}$. albicans ve $18 \mathrm{C}$. tropicalis suslarından hiçbirinde biyofilm pozitifliği saptanamazken, bu sușlar XTT indirgenmesi yöntemiyle güçlü biyofilm pozitif bulunmuștur ${ }^{[15]}$. Üriner katateri olan ve olmayan $25^{\prime}$ er hastadan izole edilen 50 Candida izolatının dahil edildiği çalıșmada XTT indirgenmesi yöntemi ve KKA yöntemiyle biyofilm olușumu araștırılmıs ve XTT yöntemiyle tüm sușlar biyofilm pozitif bulunurken, KKA yöntemiyle 50 sușun 12 'sinde biyofilm pozitifliği saptanmıștır ${ }^{[16]}$. Saxena ve arkadașları 120 Candida sușlarında biyofilm olușumunu araștırmıs, \%38.3 biyofilm pozitifliği rapor etmișlerdir. Biyofilm pozitif olarak belirlenen sușların \%27.7'sinin güçlü pozitif, \%78.2'sinin zayıf pozitif olduğunu bildirmișlerdir ${ }^{[17]}$. Yıldırım ve arkadașları yaptıkları çalıșmada $C$. albicans ve non-albicans Candida sușlarında biyofilm olușu$\mathrm{mu}$, fosfolipaz, esteraz gibi faktörlerini araștırmı olup 92 C. albicans sușunun 16'sında (\%17), 40 non-albicans Candida sușunun 13'ünde (\%33) biyofilm olușumunu gözlemlediklerini bildirmișler$\operatorname{dir}^{[18]}$. Arslan ve arkadașları yaptıkları calıșmada 100 adet $C$. albicans sușunun \%48'inde biyofilm 
varlığını rapor etmișlerdir ${ }^{[4]}$. 216 Candida türünün dahil edildiği bir çalıșmada biyofilm olușumu XTT yöntemiyle araștırılmıș olup, 128'inin (\%59.3) C. albicans olduğu ve bu izolatların 20'sinde (\%15.6) biyofilm pozitifliği rapor edilmiștir ${ }^{[19]}$.

Calıșmamızda sușların amfoterisin B, flusitozin, kaspofungin, vorikonazol, flukonazole karș1 duyarlılıkları ve bu antifungallerin MIK değerleri belirlenmiștir. Ülkemizde amfoterisin B için direnç tespit edilemeyen calıșmalar bulunduğu gibi \%57.8'e kadar direnç tespit edilen calıșmalar da mevcuttur ${ }^{[20-22]}$. Calıșmamızda amfoterisin B için incelenen 60 C. albicans içinde 4 (\%6.66) duyarlı, 56 (\%93.6) dirençli sușa rastlanılmıștır. Amfoterisin B direnç oranları yapılan calıșmalarla kıyaslandığında çalıșmamızda yüksek oranda direnç tespit edilmiștir. Atalay ve arkadașlarının yaptıkları calıșmada idrar örneğinden izole edilen 61 Candida spp. izolatında, amfoterisin B'ye karș duyarlılıkları E-test yöntemiyle incelenmiș olup MiK aralıkları 0.002-0.5 $\mathrm{\mu g} / \mathrm{mL}$ arasında tespit edilmiș ve dirençli izolat bulunamamıștır ${ }^{[23]}$.

Flukonazol, C. albicans sușları için MiK düzeyi düșük olan bir ilaçtır. Flukonazol tedavisinde en önemli problem $C$. albicans dıșındaki türlerde olușan dirençtir ${ }^{[24]}$. Calıșmamızda flukonazol için incelenen 60 C. albicans türünde 54 (\%90) duyarlı, 6 (\%10) dirençli suș tespit edilmiștir. Flukonazol için yaptığımız calıșma diğer verilerle kıyaslandığında çalıșmamızın duyarlılık oranı yüksek bulunmuștur. 100 Candida sușunun dahil edildiği çalıșmada bir Candida türlerinin 23'ünün (\%23) flukonazole duyarlı, 37'sinin (\%37) doza bağlı duyarlı, 40'ının (\%40) dirençli olduğu saptanmıștır. Calıșmadaki 54 C. albicans izolatının 18 'i (\%33.3) duyarlı, 11'i (\%20.4) doza bağlı duyarlı ve 25’i (\%46.3) dirençli olarak belirlenmiștir ${ }^{[18]}$. Yashavant ve arkadașları C. albicans için yaptığı çalıșmada flukonazol için \%80'inin duyarlı, \%10'unun doza bağlı duyarlı, \%10'unun dirençli olduğunu bildirmiștir [25].

Calıșmamızda 60 C. albicans izolatının 7'sinin (\%11.6) vorikonazole duyarli, 53'ünün (\%83.3) dirençli olduğu tespit edilmiștir. Calıșmamızda vorikonazol için direnç oranları, yapılan diğer calıșmalara kıyasla yüksek bulunmuștur. Elfeky ve arkadașları yaptıkları çalıșmada $C$. albicans izolatının vorikonazole direnc oranını \%10.5 olarak belirlemiștir $^{[26]}$. Ying ve arkadașları vulvovajinal kandidiyazisli hastalardan izole edilen $C$. albicans için yaptıkları çalıșmada vorikonazol için \%81 duyarlı, \%5 doza bağlı duyarlı, \%14 dirençli izolat tespit etmiștir ${ }^{[27]}$. Yapllan bir calıșmada Candida türlerinin 75'inin (\%75) kaspofungine duyarlı, 12 'sinin (\%12) orta duyarl,, 13'ünün (\%13) dirençli olduğu tespit edilmiștir ${ }^{[28]}$. Pfaller ve arkadașları flukonazole dirençi 351 Candida izolatı ile yaptıkları calıșmada, sușların \%99'unun kaspofungine duyarlı olduğunu (MIK $\leq 2 \mu \mathrm{g} / \mathrm{mL}$ ), 8 izolatın MiK değerinin $\geq 8 \mu \mathrm{g} / \mathrm{mL}$ olduğunu bildirmișlerdir. Bununla birlikte, bu 8 susun laboratuvar kaynakli glukan sentez mutasyonlu türler olduğu rapor edilmiștir ${ }^{[29]}$. Toner ve arkadașları ise yaptıkları calıșmada idrar örneklerinden izole edilen Candida türlerinde kaspofungine dirençli izolat saptamamıstir ${ }^{[30]}$.

Sonuc olarak, Candida infeksiyonlarında biyofilm üreten suşların virulansının ve antibiyotiklere direnç oranlarının daha yüksek oldukları görülmüștür. Biyofilm olușumunun tespitinde Kongo Kırmızısı Agar yöntemi ekonomik açıdan uygun ve rahat uygulanabilen bir yöntemdir. Mikroplakta XTT yöntemi ile biyofilm oluşumunun test edilmesi ise iki saatte sonuc verebilmesi, sonucların objektif olarak değerlendirilebilmesi, yüzeye tutunan biyofilm hücrelerini koparma ișlemi gerektirmediğinden biyofilm olușumunu saptamada kullanılabilen tutarl1 yöntemlerden biridir. Ancak maliyet açısından KKA yöntemine göre oldukça pahalıdır. Bu nedenle Kongo Kırmızısı Agar yönteminin biyofilm olușumunu saptamada daha maliyet etkin olduğu sonucuna ulașılmıștır. Bu türlerin antifungal ilaçlara direncinin yüksek olması sebebiyle Candida infeksiyonlarında etkenin tür düzeyinde tanımlanıp antifungal duyarlılıklarının belirlenmesi ve uygun tedavinin sağlanmasının, direnç gelișiminin engellenebilmesi açısından faydalı olabileceği düșünülmektedir.

\section{ETIK KURUL ONAYI}

Calıșma için Kahramanmaras Sütçü İmam Üniversitesi Tıp Fakültesi Bilimsel Araștırmalar Etik Kurulundan onay alındı (Karar no: 247 Tarih: 02.11.2016).

\section{ÇIKAR ÇATIŞMASI}

Yazarlar bu makale ile ilgili herhangi bir çkar catıșması bildirmemișlerdir. 


\section{YAZAR KATKISI}

Anafikir/Planlama: SA, MA

Analiz/Yorum: SA, MA, BK

Veri Sağlama: SA, BK, KD

Yazım: SA, BK, KD

Gözden Geçirme ve Düzeltme: BK, MA, KD

Onaylama: SA, BK, MA, KD

\section{KAYNAKLAR}

1. Tümbay E. Kandida türleri. In: Ustaçelebi Ş (ed). Temel ve Klinik Mikrobiyoloji. Ankara, 1999:1081-5.

2. Yakupoğulları Y, Toraman Z. Çeşitli klinik örneklerden soyutlanan Candida kökenlerinde slime faktörü üretiminin araştırılması. Türk Mikrobiyol Cem Derg 2004;34(3):178-81.

3. Birinci A, Çekiç Cihan Ç, Bilgin K, Acuner Ç, Durupınar B. Candida türlerinde slime üretiminin araştırılması. Turk Mikrobiyol Cem Derg 2005;35:163-6.

4. Arslan U, Fındık D. Klinik örneklerden izole edilen Candida albicans türü maya mantarlarında virulans faktörlerinin (proteinaz, slime ve fosfolipaz) in-vitro araştırılması. Infeksiyon Dergisi 2003;17(4):471-81.

5. Hilmioğlu S, ilkit M, Çavuşaoğlu C, Aydemir Ş, Tümbay E. Candida izolatlarında slime üretiminin üç ayrı yöntemle gösterilmesi ve slaym üretiminin kristal viyole reaksiyonu ile ilişkisi. Infeks Derg 1999;13:183-6.

6. Roehm NW, Rodgers GH, Hatfield SM, Glasebrook AL. An improved colorimetric assay for cell proliferation and viability utulizing the tetrazolium salt XTT. J Immunol Methods 1991;142:257-65.

7. Arendrup MC, Melatiadis J, Mouton JW, Lagrou K, Hamal $P$, Guinea J, et al; Subcommittee on Antifungal Susceptibility Testing (AFST) of the ESCMID European Committee for Antimicrobial Susceptibility Testing (EUCAST). EUCAST definitive document EDEF 7.3.1 January 2017: Method For The Determination of The Broth Dilution Minimum Inhibitory Concentrations Of Antifungal Agents For Yeast.

8. Clinical and Laboratory Standard Institute (CLSI). Performance standards for antifungal susceptibility testing of yeasts. CLSI Suppl M60, 2017.

9. Richards MJ, Edwards JR, Culver DH, Gaynes RP. Nosocomial infections in pediatric intensive care units in the United States. National Nosocomial Infections Surveillance System. Pediatrics 1999;103(4):e39.

10. Kalkancı A, Yalınay Ç, Mansuroğlu H, Kuştimur S. Candida türlerinde slaym faktör belirlenmesi. Türk Mikrobiyol Cem Derg 1999;29:183-5.

11. Ramage G, Bachmann S, Patterson TF, Wickes BL, López-Ribot JL. Investigation of multidrug efflux pumps in relation to fluconazole resistance in Candida albicans biofilms. J Antimicrob Chemotherapy 2002;49(6):973-80.

12. Karaman M, Alvandian A, Bahar iH. Candida albicans biyofilm etkilerinin değerlendirilmesinde Galleria mellonella larvası modeli. Mikrobiyol Bul 2017;51(1):32-40.
13. Jabra-Rizk MA, Falkler WA, Meiller TF. Fungal biofilms and drug resistance. Emerg Infect Dis 2004;10(1):14.

14. Özcan SK. Tıbbi gereçlerle ilişkili Candida biyofilm ve infeksiyonları. Turkiye Klinikleri J Med Sci 2007;27(4):589-600.

15. Aslan H, Gülmez D. Üriner Candida izolatlarının biyofilm yapabilme özelliğinin üriner kateter kullanımı ile ilişkisinin araştırılması ve biyofilm varlığında antifungal duyarlılık durumunun değişimi. Mikrobiyol Bul 2016;50(2):256-65.

16. Arslan H. Candida Türlerinde Biyofilm Oluşumu ve Antifungal Duyarlılı̆ga Etkisi. T.C Hacettepe Üniversitesi Sağlık Bilimleri Enstitüsü, Yüksek Lisans Tezi. 2015;61-3.

17. Saxena $N$, Maheshwari D, Dadhich D, Singh S. Evaluation of Congo Red Agar for detection of biofilm production by various clinical Candida isolates. I Evolution Med Dent Sci 2014;3(59):13234-9.

18. Yıldırım M, Mumcuoğlu i, Kurşun Ş, Koldaş K, Yetener V, Balaban N. Infeksiyon etkeni olarak izole edilen Candida albicans ve non-albicans Candida suşlarındaki bazı virulans faktörlerinin karşılaştırılması. Türk Mikrobiyoloji Cemiyeti Dergisi 2009;39(3-4):62-8.

19. Tüzüner $U$, inci R. Candida türlerinde biyofilm oluşumunun modifiye mikroplak ve modifiye XTT redüksiyon yöntemleri ile saptanması. Ege Tıp Dergisi 2017;56(4):178-82.

20. Koç N. Ülkemizde antifungal direnç. 3. Ulusal Mantar HastaIıkları ve Klinik Mikoloji Kongre Kitabı, 27-30 Mayıs 2003, Bodrum. Türk Mikrobiyoloji Cemiyeti Yayını. 2003;46:285-300.

21. Hassan Hassan AB. Yoğun Bakım Hastalarının Idrar Kültüründen Izole Edilen Candida Türlerinin Dağılımı ve Antifungal Duyarlılıklarının Belirlenmesi. T.C. Gaziantep Üniversitesi Sağlık Bilimleri Enstitüsü, Yüksek Lisans Tezi. 2018;58-65.

22. Cilo BD, Topaç T, Ağca H, Sağlam S, Efe K, Ener B. Candida Izolatlarının Antifungal Duyarlılığının Belirlenmesinde Klinik Laboratuvar Standartları Enstitüsü (CLSI) ve Avrupa Antimikrobiyal Duyarlılık Testleri Komitesi (EUCAST) SIVı Mikrodilüsyon Yöntemlerinin Karşılaştırılması. Mikrobiyol Bul 2018;52(1):35-48.

23. Atalay MA, Koç AN, Sav H, Demir G. Yatan hastaların idrar kültürlerinden izole edilen Candida türleri ve antifungal duyarlılıkları. Turk Hij Den Biyol Derg 2013;70(4):185-90.

24. Aktaş F. Kandidüri ve üriner sistem kandidiyazisi. In: Doğanay M, Ünal S, Çetinkaya Şardan Y (eds). Hastane Infeksiyonları, Bilimsel Tıp Yayınevi. 2008;2:191-7.

25. Yashavanth $R$, Shiju M, Bhaskar U, Ronald R, Anita K. Candiduria: prevalence and trends in antifungal susceptibility in a tertiary care hospital of mangalore. JCDR 2013;7(11):2459.

26. ElFeky DS, Gohar NM, El-Seidi EA, Ezzat MM, AboElew SH. Species identification and antifungal susceptibility pattern of Candida isolates in cases of vulvovaginal candidiasis. Alexandria J Med 2016;52(3):269-77.

27. Ying $C$, Zhang H, Tang Z, Chen H, Gao J, Yue C. Antifungal susceptibility and molecular typing of 115 Candida albicans isolates obtained from vulvovaginal candidiasis patients in 3 Shanghai maternity hospitals. Sabouraudia 2015;54(4):394-9. 
28. Hösükoğlu Çelikkan GF. Vajinal Örneklerden izole Edilen Candidaların Tiplendirilmesi Ve Broth Mikrodilüsyon Yöntemi ile Antifungal Duyarlılıkarının Belirlenmesi. T.C. Gaziantep Üniversitesi Sağlık Bilimleri Enstitüsü, Yüksek Lisans Tezi. 2017;69-73.

29. Pfaller MA, Messer SA, Boyken L, Rice C, Tendolkar S, Hollis RJ, et al. Caspofungin activity against clinical isolates of fluconazole-resistant Candida. I Clin Microbiol 2003;41(12):5729-31.

30. Toner L, Papa N, Aliyu SH, Dev H, Lawrentschuk N, Al-Hayek S. Candida growth in urine cultures: a contemporary analysis of species and antifungal susceptibility profiles. QJM: An Int J Med 2015;109(5):325-9.

\section{Yazıșma Adresi/Address for Correspondence} Dr. Burak KÜĊU்K

Kahramanmaras Sütçü İmam Üniversitesi Tıp Fakültesi, Tibbi Mikrobiyoloji Anabilim Dalı, Kahramanmaras-Türkiye

E-posta: dr.burakkucuk@gmail.com 